\title{
A Language Course to Teach Administrative Staff English for Communication in an International University
}

\author{
Barry Lee Reynolds \\ https://orcid.org/0000-0002-3984-2059 \\ Faculty of Education, Centre for \\ Cognitive and Brain Sciences, \\ University of Macau, China \\ barryreynolds@um.edu.mo
}

\author{
Melissa H. Yu \\ https://orcid.org/0000-0003-2594-5732 \\ Faculty of Education, \\ University of Macau, China \\ huiyenyu@um.edu.mo
}

\section{Abstract}

A qualitative case study was conducted to triangulate student interviews, a teacher's reflection report, and classroom observation data to understand how a local language course prepared Taiwanese administrative staff for international communication across working contexts in an international university. The findings firstly show that the teacher treated course planning as a teacher and student process of co-developing, co-moderating, co-revising, and co-managing learning resources and content. The teacher empowered the administrative staff by giving them the authority to select language targets for study that the staff thought would be useful to fulfil their job duties. Secondly, participation of the administrative staff was important in creating and managing language resources for international communication. The teacher used vocabulary and dialogue writing and speaking practices that were contextualised to the needs of the administrative staff. The targeted vocabulary was selected by the administrative staff based on gaps in their knowledge and was then used to co-construct dialogues that addressed scenarios the staff had previously encountered that necessitated the use of English with internationals. Thirdly, developing the course to address the administrative staff's communication needs was a process of rebalancing teacher autonomy, learner autonomy, and course development. Both the teacher and the students perceived the course effective in encouraging practical changes in the administrative staff's learning and use of English, which they mostly attributed to the non-formal nature of the course and the support from higher management. Implications for planning and implementing English

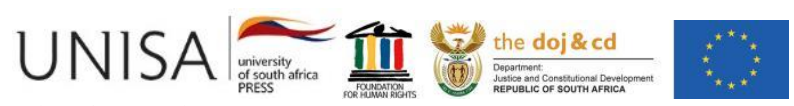

Education as Change

https://doi.org/10.25159/1947-9417/8749

https://upjournals.co.za/index.php/EAC

ISSN 1947-9417 (Online)

Volume 25 | 2021 | \#8749| 29 pages

(C) The Author(s) 2021 
language courses for international communication were drawn from the findings.

Keywords: EIL; ELF; WE; course development; materials development; teaching English for administrative purposes; teacher autonomy; learner autonomy

\section{Introduction}

The varying nature of communicative language use in global contexts has resulted in the establishment of several paradigms used to illuminate communicative phenomena in various global situations. For example, some English as a lingua franca (ELF) scholars argue for a non-static dynamic perspective that conceptualises linguistic and cultural resources emerging from or embedded in international communicative discourse (Baker 2015; Jenkins 2015). Expanding the scope of multilingualism, Pennycook and Otsuji $(2015,180)$ argue that English is not simply a language used as a lingua franca or used in prescribed context(s), but a "highly variable multilingual franca". Following this, Pennycook and Otsuji $(2015,180)$ coined the term "metrolingua franca" to highlight communicative English language use with a "spatial repertoire" emergent from diverse communication places as well as with the interactive connection to the local language practice and contexts.

The afore-cited paradigms (that is, ELF and metrolingua franca) have made considerable advancements in understanding English language use in global contexts. Furthermore, the paradigmatic knowledge about English for international communication has formed an academic think tank, offering scholars ideas and research routes to reconsider established English language courses and professional training programmes. Still, it is questionable whether the learners' needs are always at the centre of this growing body of research. Recently, Rose, McKinley, and Galloway (2021) conducted a review of pedagogical research showcasing the trajectory of English as a global lingua franca. Their review highlights researchers' overindulgence in theoretical "jibber-jabber" alongside a severe lack of longitudinal research designs aimed at investigating classroom contexts outside the traditional university language classroom. The debates about the needs of "multicompetent speakers" are questionable because it is not always clear whose interests these debates serve. The divide between theory and practice is shortening (Rose, McKinley, and Galloway 2021), but without inviting learners to take part in this process.

Over the past five years, research in EFL (English as a foreign language) or ESL (English as a second language) contexts has examined the application of ELF, WE (World Englishes), or EIL (English as an international language) to design courses. The studies aimed to 1) create opportunities for students to explore topics about English and its use in global communicative contexts, 2) discuss how courses influence students' perceptions of introduced topics, and 3) consider the implications of the introduction of concepts. For instance, Chang (2014) planned and taught a two-hour weekly course, World Englishes, in which 22 undergraduates participated and reflected on which 
topic(s) informed their learning the most. The course helped Taiwanese undergraduates "re-examine some of their deep-rooted beliefs about English" (Chang 2014, 24) and redefined "the purpose of language learning" (Chang 2014, 25). For those participants who wished to become English language teachers in the future, integrating "WE into existing curriculums" (Chang 2014, 26) became one pedagogical option.

Similar studies were conducted to document how the concepts of EIL or ELF have been applied to innovate existing TESOL (teaching English to speakers of other languages) teacher training programmes in ESL contexts (Kang 2017) or plan new ELF-based courses in EFL contexts (Fang and Ren 2018). Specifically, Kang (2017) investigated how the concepts of EIL were incorporated into an existing United States-based teacher training programme. Kang's study identified a transformative versus reserved perspective among Chinese and Korean teacher trainees. This bimodal perspective was reflected in the extent to which their teaching could be considered EIL-oriented after receiving the training. Similarly, Fang and Ren (2018) found teaching a Global Englishes course to undergraduates effectively developed students' awareness of linguistic diversity, motivated them to challenge the native-speaking (NS) normative approach to developing communicative competence, and left the students with a positive perception of global Englishes. The reviewed courses/programmes focused on how theoretical constructs of WE, EIL or ELF influenced students' or teacher trainees' perceptions of English language and its use (Chang 2014). Although these and similar studies on EIL/ELF-framed courses have provided valuable insights into participants' perceptual changes about English language and its communicative use, an insufficient amount of discussion has taken place about the potential of participants' perceptual changes bringing about practical changes in English use or acquisition.

Unlike the reviewed studies that focused on the execution of courses, Sung (2018) designed an out-of-class activity attached to an English language course. In Sung's study, 18 undergraduates used the English learned inside the classroom to communicate with international students outside the classroom. The analysis of students' weekly record of communicative language use and end-of-semester reflection reports showed that their real-world communication experience changed their perceptions of English language use. They came to appreciate the linguistic diversity of English, which challenged the native-speaking linguistic norms and ensured the legitimacy of intelligible English language use. They also grasped "the importance of communicative strategies" while recognising "the value of multilingual resources" (Sung 2018, 21). Students expressed how they benefited from this course: it provided opportunities for them to become English language users and to practise applying strategies to establish intercultural partnerships in global communication contexts. Sung's (2018) investigation pointed to a new research direction when he explored how these 18 undergraduates understood ELF based on their communicative experiences. In other words, Sung was more focused on the student perspective. Unlike other studies (Fang and Ren 2018), Sung (2018) did not select specific WE, EIL, or ELF concepts to 
incorporate into the course. The course did not subject the students to a prescribed scope of understanding about these international communication phenomena.

The reviewed literature shows a tendency for researchers who ascribe to a WE, EIL or ELF mindset to reject the native-speaking Standard English, and the monolingual normative approaches to teach and learn English (Dogancay-Aktuna and Hardman 2018). The rejection of more traditional approaches by those who advocate modern language learning ideologies has created a new polarised way of thinking about international English pedagogy. Regardless of whether we looked to empirical research articles or book volumes, the existing literature highlighted the pedagogical value of rejecting particular perspectives for teaching and learning English. Examples include discussions of the linguistic normative dominance in teaching and learning materials ( $\mathrm{Yu}$ 2015), international language assessment systems (Jenkins and Leung 2016), English language curriculum (Xu 2018), and pedagogical ideas and praxis (Galloway and Rose 2018; Matsuda 2017), among others. Clearly, rejecting particular approaches to teaching and learning has become the backbone of international English language pedagogy, forming a picture of what mainstream international English language courses should look like. Instead of targeting a linguistic ideology as a scapegoat, it is important to understand whether an approach has become the main factor that has steered the teaching and learning of English away from international communication in local contexts.

Although in the past three decades rejecting a linguistic normative approach and raising the awareness of English linguistic diversity have become the mainstream of international English language pedagogy, it should not be seen as the only or even the primary way to frame pedagogy. There is no one-size-fits-all approach to the teaching of the English language. Besides, rejecting the linguistic normative approach may be necessary for one teaching context or one student cohort but not for another. For instance, raising students' awareness of the linguistic diversity of English was found to be quite helpful for one Taiwanese student cohort (Chang 2014), but not necessarily an urgent need for another (Yu 2018). While placing reliance on rejecting the linguistic normative approach to frame international English language courses has formed a dominant way to think of ELF pedagogy, other ways to think about glocal pedagogy should also be identified. As McKay and Brown $(2016,60)$ have argued, "the final decision on whether or not to adopt, adapt, or develop a locally defined EIL course should depend not only on the teacher's beliefs but also on factors in the local context that need to be thought through". The current study identified how a teacher planned and implemented an English for international communication course specifically for one student cohort.

As Leung and Lewkowicz $(2018,70)$ argue, "teachers themselves could determine what is relevant for their learners in terms of models of language and language use, in addition to (or even instead of) the ones imposed by others including textbooks and official curriculum statements". Expanding this argument, we feel that developing an English 
language course for international communication should not be restricted to any prescribed or unidirectional scope. We are aware that there are particular strengths and weaknesses associated with adopting or adapting EIL, ELF, and WE paradigms to teach English for international communication. We also are aware of the dangers in assuming any particular English language user will or will not encounter any particular international community situation that may or may not require English language use. Thus, it is not feasible for us to suggest which paradigm is more or less suited for any number of scenarios that can or cannot be foreseen. Instead, this article has begun with a balanced approach to reviewing previous literature by discussing empirical studies framed within these research paradigms. We use the term EIL as an alternative to ELF or WE; however, we draw upon the paradigmatic knowledge of the latter to explain the international communicative use, learning, and teaching of English in the course analysed. We analysed both how an in-service teacher designed and delivered a language course aimed at developing students' international communicative competence and what the learning outcomes were.

\section{Methodology}

A qualitative case study method was adopted to explore an English language course designed by a local in-service teacher to develop students' communicative competence. This methodological decision corresponds to one of Stake's (1995) suggestions for conducting qualitative case studies by identifying which activities will and will not be discussed in the studied case. Within this framework, the focus of this study was on the locally designed English language course, not on a course focused on incorporating EIL theoretical constructs. The theoretical constructs of EIL are drawn upon to discuss the analysis of this qualitative case study, not to frame this study in terms of pre-determining which learning activities are or are not related to English for international communication. This methodological decision also corresponds to Richards's (2003) point about taking a critical perspective when framing a research study by not beginning the project with a paradigmatic alignment. An open approach was necessary to interpret what an international English language course meant to a local in-service teacher and his students, not what such a course should look like according to the existing literature.

\section{Research Questions}

Three questions were formed to address the concerns that arose from the literature discussed above.

1. When planning and teaching the language course, what did the teacher prioritise to teach administrative staff students in order to help them communicate with international students in a university?

2. What were the main teaching/learning principles used to design and implement the language course? 
3. Did the administrative staff students and teacher perceive this language course effective in encouraging the use of English at workplaces for international communication?

\section{Research Context}

This case study was conducted at an international university in Taiwan. Due to the internationalisation of higher education in Taiwan, the number of international students increased in this university. With the 28 international students enrolled in courses in the School of Management, the administrative staff in this university reported to the School of Management Dean about their needs when using English to communicate with international students. To address the administrative staff's language needs, the dean decided to plan a four-month language course to develop the administrative staff's communicative competence. This course was not compulsory, so it was the administrative staff and not the dean who decided that they needed this language training.

\section{Participants}

Twenty female administrative staff (students, henceforth) enrolled in the language course and were divided into four groups of five students each. Each student had the opportunity to meet the teacher once a week for an hour. Before this course, each student had received between six and 10 years' English language education within the Taiwanese national education system. Apart from the international English language use experience at the university, most students had few opportunities to use English for communication on a daily basis.

Before the data collection, all students received an email with information about the purposes of the current study, the voluntary research activities, and the ways their confidentiality as participants would be ensured. The students were informed that their attendance and language performance would not affect any work review. All students were provided with opportunities to ask questions about this study. Based on the students' understanding of this research, all students who enrolled in this course agreed to take part in this study. While all students agreed to be videoed in class, only seven students agreed to be interviewed. Only two students agreed to write reflection reports about their learning experiences.

This case study also recruited a native-speaking teacher of English who completed his undergraduate and master's degree studies in the United States (US) and PhD study in Taiwan. At the time of the study, the teacher had two years' ESL teaching experience in the US context and 11 years' EFL teaching experience in the Taiwanese context. In the US, he mainly taught academic reading and academic oral skills courses. After arriving to Taiwan, he taught a wide range of English language courses at different universities, including teaching EFL skills-based courses, introductory English literature courses, English for Specific Purposes (ESP) courses, and English for 
Academic Purposes (EAP) courses. None of these courses had a direct link with the concepts of EIL and related pedagogical paradigms. Yet, he had experience teaching English for communication purposes to different student cohorts in the US and Taiwan.

The teacher and the students had a collegial and professional relationship. Although the main purpose of the teacher's interactions with the students during class was to assist with their learning of English for communication purposes, due to the similarity in age, interests, and life experiences, some of the students felt comfortable enough to approach the teacher outside class to converse with him about their work lives and struggles. This may have given him an advantage in course design as he could draw upon the language difficulties the students shared with him to steer the course in particular directions to meet students' needs.

\section{Data Collection and Analysis}

This study analysed 1) interviews with seven students and one teacher, 2) the reflection reports of two students and one teacher, and 3) two hours of video showing 20 students practising English conversation with student-written dialogues. Qualitative research often has small sample sizes as it is fundamental to methods of inquiry such as case study (Creswell 2019); the data collected for the current study was adequate for addressing the three research questions. Furthermore, as the video recording was of students' active engagement in communicative language use, it provided rich data (Given 2008).

\section{Teacher and Student Reflection Reports}

The students were offered a guide with questions to help them reflect on the process and results of learning from the course (see Appendix 1). Two of them provided reflection reports after this course. The researchers asked the teacher to write an open-ended reflection report that included a discussion on the topics he thought an English language course for international communication should cover; the teacher had a set of topics to structure the reflection report (see Appendix 2). The reflection focused on the development of the course and how the teacher planned and taught the course.

\section{Interviews}

Based on the preliminary analysis of the teacher's reflection report, two sets of interview questions were formulated to carry out two email interviews with the teacher (see Appendix 3). The first interview focused on how the teacher planned this language course and the underlying theories to support his pedagogical decisions. The other set of questions used for the second interview explored the foci, strategies, principles, and evaluation of teaching and learning. Seven out of 20 students volunteered to be interviewed at the end of this course (see Appendix 4). These students chose to be interviewed in English but some of them used Chinese to clarify their intended meanings when necessary. The teacher also chose to be interviewed in English although he is a fluent Chinese speaker. 


\section{Observational Videos}

Classroom observational videos were made to record students' language practice when using the dialogues they wrote. From the beginning of the course, the teacher positioned a video camera at the front of the classroom to make the students familiar with its presence. However, the video camera was only turned on when the students were engaged in communicative conversation practice. This type of data was used as a supplementary resource to support the discussion of the findings that resulted from the analysis of the interviews and reflection reports.

\section{Interpretative Content Analysis}

All interviews and observational videos were transcribed verbatim. Interpretive content analysis was carried out to analyse the data by referring to relevant contextual information with the aim to answer three what-and-how research questions (Drisko and Maschi 2013). Interpretive content analysis can deepen the understanding of the meanings of text contents as a result of the increase of research validity (Drisko and Maschi 2013).

\section{Coding}

Coding was carried out according to the existing main themes, which emerged from the reviewed literature, namely, "what to teach", "how to teach", and "course usefulness". Through rereading, cross-referencing, labelling, and categorising the data, six subthemes emerged. Regarding "what to teach", two subthemes were identified: "learner needs" and "using a vocabulary list to write international communication dialogues". The two subthemes "practise using English to interact" and "underpinning teaching principles" emerged from the main theme "how to teach". For the main theme "course usefulness", the following subthemes emerged: "teacher's evaluation" and "students' evaluation". The findings of this study presented below address the three research questions.

\section{Findings and Discussion}

\section{When planning and teaching the language course, what did the teacher prioritise to teach students in order to help them communicate with international students in a university?}

The teacher began planning and teaching this course by producing materials collaboratively with the students. Prior to this course, the teacher indicated that the Dean of the School of Management gave him a vocabulary list, which included the names of buildings/departments/faculties at the university and administrative terms for the students to familiarise themselves with. Addressing students' needs by learning and using profession-related words echoes the educational conventions or language need assessment discussed by research in the fields of ESP and EAP (Coxhead 2018; Wang, Liang, and Ge 2008). However, as will be described below, the students created their own vocabulary lists based on their need to use English in their workplace. 
In addition to the word list provided by the dean, the teacher let students create a new word list. Students proposed the words that they wished they knew in English because they had encountered a situation in which they needed to know a term in English but did not know it. The students were also encouraged by the teacher to share words with each other so that they could compare unknown and known words to help build up the new word list. The students' vocabulary list derived from their language use experience and directly addressed their language learning needs. This was different from the word list provided by the dean who made the list based on his assumptions about what vocabulary the staff may need. So, learning to use the words identified by each student ensured the relevance of the content of vocabulary learning to their language use. "Encouraging learners to connect with the language in their personal lives" increases language authenticity (Pinner 2016, 49).

In addition, the teacher designed a learning activity to co-produce learning materials by writing communicative dialogues with students. The teacher co-produced dialogues based on the information he gathered from the students' reports on their communicative experiences in their workplace. The students were then given copies of the dialogues typed by the teacher and "encouraged to read and discuss the dialogues in order to explain and share with one another" (Teacher interview one) and revise them. The teacher indicated that the rationale behind this activity was that "students may have different communicative experience in different international contexts" (Teacher interview two). In other words, "even though [administrative] staff were working in [the same] university" (Teacher interview one), they held different administrative positions engaging in dissimilar communicative activities that shaped each student's linguistic repertoire. Extract $1^{1}$ below illustrates an example of the spoken language produced based on one of the written dialogues. The teacher's conception of the relationship between the students' language use and multiple communicative contexts echoes Hall, Cheng, and Carlson's $(2006,232)$ point that language should not be conceptualised as "a-context-bound language system".

\section{Extract 1}

A: Hello Mr C, I'm D, a graduate student from the Department of Business Administration. I have a question regarding student scholarships. Could you please tell me how to apply?

B: I'm not familiar with the process either but I can ask if someone can help you. Please wait here for a few minutes.

A: Sure, uh that is so kind of you. Thank you.

B: Okay, D. I contact the office of international affairs regarding your inquiry. The office informed me that you must submit an application before July 15 th in order to

1 The transcription conventions used can be found in Appendix 5. It should also be noted that these are transcriptions of the videoed communicative interactions of the students and not the written dialogues. 
apply. This application must include a completed application form with an attached photo, uh your latest academic transcript, a copy of your ARC, and a copy of your passport. Here is the application form.

Extract 1 above shows content grounded in students' own language knowledge and resources emerging from their real-world communication experience across professional contexts. As Widdowson $(1998,711)$ observed, "real language, then, is local language in that it is always associated with specific contextual realities". The content of learning also did not illustrate pre-packaged language knowledge presented in traditional textbooks for students to learn, as Yu (2018) has discussed. The dialoguebased learning materials represented the students' knowledge about language use in communication activities for administrative purposes. This finding aligned with Hall Cheng, and Carlson's $(2006,232)$ point that language is "grounded in and emergent from language use in concrete social activity for specific purposes".

In sum, the results firstly indicate that the teacher's way of thinking about learning materials was not tied to any set of predetermined linguistic resources for students to learn from. The content was not based on prior assumptions about which set of ELF/EIL-related language knowledge ought to be incorporated into locally designed courses (Chang 2014; Fang and Ren 2018). To be specific, the language knowledge concerning learning and using EIL for communication was not tied to any fixed ways of understanding the English language and its use. The vocabulary list and dialogues developed by the students illustrated how international English language communication was used across glocal working contexts in multiple ways to complete administrative tasks. The learning materials depicting students' language use experience corresponded to Tomlinson and Masuhara's (2010) conceptualisation of authentic materials: they should "provide an experience of the language in use" $(2010,400)$. Most of the learning resources were proposed and produced by the students. The students decided which learning materials and content would be used in the course. In contrast, the teacher assisted the students by collecting and managing the learning materials. The role of the teacher was that of a material manager, not a learning material writer, provider, or decision maker.

\section{What were the main teaching/learning principles used to design and implement the language course?}

This section explores the underlying principles that supported the teacher's decision on what and how to teach. Firstly, the teacher felt that the students' jobs "required the knowledge of certain administrative vocabulary that they did not know, and these needed to be understood so they could communicate with the internationals on campus" (Teacher interview one). The idea of learning professional vocabulary to express intended messages was also recognised as an essential skill for nurses to communicate with international patients or healthcare providers in Taiwan (Lu 2018). Secondly, the teacher thought that this course should focus on "the target vocabulary that they [students] had previously mentioned that they needed to know" (Teacher interview one) 
for work. The teacher's idea of familiarising students with vocabulary needed for work echoes McKay and Brown's $(2016,61)$ argument for EIL instruction to set realistic learning goals by assessing students' needs. Thirdly, if one student "encountered this need then maybe another would as well" (Teacher interview one) and constructing the vocabulary list created an opportunity for the students to explore vocabulary they may encounter in the future. Lastly, the teacher encouraged the students to choose words they needed to learn for work purposes. Selecting words to express meaning at workplaces echoes Nation's (2013) point about learning well-selected words. Nation $(2013,14)$ observed that "a relatively small amount of well-chosen vocabulary can allow learners to do a lot". It is important that students are learning practicable vocabulary.

The teacher felt he "could understand ... the problems or information that [international] students may need" and could help the students in his class by providing support through the co-construction of English dialogues. The teacher and students discussed "what was wrong with the dialogues that the teacher had co-written" and then the "[students] would suggest changes". According to the teacher, "about $50 \%$ of the dialogues would be changed". After two months of doing this, the teacher advised the students "to generate discussion in class and write ... dialogues" on their own with the help of their vocabulary list; they were encouraged to draw upon their resources.

When the teacher was asked for the reasons behind asking the students to create the learning materials (that is, dialogues) on their own, he firstly replied that he wanted to "show students that they had the language amongst them if they only worked together to share their knowledge. In a community of practice they could share with one another what would be needed to perform their job duties." Through this process, the students learned how to use English to communicate with international students by interacting and negotiating with their colleagues who had similar experiences. Secondly, the teacher reported, "I could not anticipate questions" about international communication that "I [had] not experience[d] in the past" and "I [could] only guess at what encounters they may have". Clearly, the teacher recognised that he could not present the unexpected communicative situations in the learning materials for the students to learn from. The teacher's response to the challenges of the unexpected communicative situations resonates with Pennycook's $(2012,131)$ observation about classrooms: "[W]e know we can only understand some of what is happening and can never know what is about to come." Thirdly, against the backdrop of the unexpected communication situations, the teacher shared in the teacher reflection report:

I did not know how long I would be able to guide students, so I knew it was up to me to give them as much support and information as possible. ... If I had to leave them, they would be able to carry on their learning independently. So, I was a support for them in writing dialogues initially but then I wanted them to be able to do so independently. ... They could empower themselves to think about how they may handle future interactions with the internationals they encountered on campus. 
The teacher's comment above reveals that while students developed learning autonomy, they also developed their communicative fluency. From the teacher's point of view, developing students' fluency and autonomy were not two separate things. The more students became autonomous in learning and using English, the better they would be able to handle communicative situations in the future when he would not be their teacher. This finding corresponds to Little's $(2007,14)$ claim that "the development of learner autonomy and the growth of target language proficiency are mutually supporting and fully integrated with each other".

The students paired off or grouped up to practise using English to communicate. When students used the dialogues to practise, they began with reading. First, there was silent reading, then the teacher's read out loud for students to hear, and then "students took turns reading". After silently reading, students paired off to "practise reading dialogues out loud" (Teacher interview two). The reading aloud was used as a warm-up and a scaffold for students who were not used to or had reservations about speaking in English. The reading aloud allowed the staff to "hear the other staff speak English" so that it might make them "more willing to speak" (Teacher interview two) in English. Finally, students were asked to "try to recall the content" of dialogues through practised conversations. All throughout the process of individual reading, group reading, and group conversing, "students used individual words or sometimes phrases to confirm their understanding of the conversation" (Teacher interview two). When the students practised the dialogues, the written dialogues were not used as a reference. Instead, the students recalled the content and practised the dialogues repeatedly. Repeatedly conversing about the same topic with different speaking partners under time pressure has been shown to result in improvements in speaking fluency (Nation 2007, 2013; Nation and Yamamoto 2012). Extract 2 illustrates an example of how two students used one of the written dialogues to practise conversing in English.

\section{Extract 2}

A: Oh, well um, but I am not very sure where the administration building is located. Can you please tell me where it is?

B: Do you know the location of library?

A: Of course! Yes, I often read books and magazines there.

B: Okay, uh the kiosk is on the side of the building facing the library. Uh by the way, the cost is $10 \mathrm{NT}$ dollars, and your academic transcript will immediately print at the kiosk after paying.

A: Oh, thank you for your explanation. Um, I will prepare you mentioned the documents you mentioned before as soon as possible. However, um, ((I)) ((uh I)) lost however, I not sure uh whether can where I can fill out the application form correctly. 
B: If you have any question regarding how to complete application form, you can either come to the department office to ask me or go directly to the office of international affairs.

A: Okay, I see. Uh, ((is there)) anything else I have to do?

B: Oh yes! Uh there is one little thing I have to I need to tell you. I need to verify the information at ((the)) information uh on the application form before you turn it into the office of international affairs. Please bring the application to the department office so I can have a look and affix the department seal before you turn it in.
A: Oh, thank you.
B: Good luck with your application.

A: Thank you, I really do ((appreciate)) your kindness.

The excerpt above illustrates the decrease of the teacher's pedagogical and linguistic intervention and the increase of students' involvement in learning English for international communication. In other words, with the teacher's guidance, the students increasingly took more responsibility and became increasingly independent learners of English. This evolutionary process also confirmed that the teacher mediated the students' autonomy development by offering guidance and limited input, as Gao (2018) has suggested. The teacher did not focus on selecting predetermined learning resources for students to learn. Instead, he managed and edited the materials to ensure their workrelated communication authenticity. Incorporating the students' international communicative experiences and language use into this course echoes the arguments put forth by Little $(1995,178)$ : developing students' learner autonomy "requires a shift in the role of the teacher from purveyor of information to facilitator of learning and manager of learning resources".

Writing and using the dialogues to practise conversing with international students were the main activities used for the teaching and learning of English. As discussed, the process of how the students wrote and used the dialogues to learn English for international communication received very little input from the teacher. Firstly, the teacher "focused mainly on the scenarios" that he "gathered from the staff in the beginning of the class" (Teacher reflection report). His version was simply "a rough draft based on what students had shared with [him]" and he knew that these dialogues "would be edited later on" (Teacher reflection report) mainly by students. The only intervention from the teacher was with helping students revise when he did not understand the texts. When the students engaged in speaking practice, "correction took place only when [he] heard something that was unintelligible" (Teacher interview two). This approach to linguistic intelligibility-oriented correction and teaching has been advocated by ELF scholars (for example, Jenkins 2000). 
Despite the students having written the dialogues themselves, the teacher felt it was unlikely for them to produce spoken English during conversation practice that exactly matched the dialogues. According to the teacher's observation, the words that students used did not necessarily "match the script words" because he wanted students to "focus on fluent communication, not on grammatical accuracy" (Teacher interview two). The evidence in the excerpts above showed that the students used English beyond any prescriptive scope (for example, Seidlhofer 2011) and they did not use English in adherence with any linguistic norms. The result also indicated that fluency was prioritised over linguistic accuracy (Hall 2014). Our support for the teacher placing more importance on communication does not indicate that we believe the eventual outcome should or should not be grammatically accurate based on any linguistic norms. Instead, norms set by a teacher should correspond with students' language learning needs and goals. In other words, if a student cohort needs to learn English that requires grammatical accuracy that aligns with a particular norm, then this should be echoed by the teacher's approach to correction and teaching.

\section{Did the administrative staff students and teacher perceive this language course effective in encouraging the use of English at workplaces for international communication?}

In this section we discuss the exploration of the students' and teacher's evaluation of the course. Since the teacher and students agreed that this course was successful, the discussion below focuses on the students' learning outcomes and which part(s) of the course helped the students to learn and use English for international communication. Then, the teacher's evaluation of this course is considered.

\section{Students' Evaluation}

When asked about how the course helped the students communicate with international students at workplaces, all students indicated that they perceived the course as helpful. Table 1 below illustrates examples of students' comments on learning outcomes. All students thought highly of their use of English for communication at their workplaces. The positive comments by the students prioritised using English to communicate with international students and using English to effectively complete their administrative tasks. 
Table 1: Students' evaluation of their learning outcomes

\begin{tabular}{|l|l|}
\hline SS1: & I think we can understand each other's what I mean and what he means. \\
\hline SS2: & I can ... and explain what I want to say. \\
\hline SS3: & $\begin{array}{l}\text { Even my work studies (students), they are natives [and] not natives they speak } \\
\text { English with me so I speak a lot of English when I work here. }\end{array}$ \\
\hline SS4: & Simple because I can answer them. @ @ \\
\hline SS5: & $\begin{array}{l}\text { I am very sure I can reply well I would reply them in English. Of course I almost } \\
\text { reply in English... }\end{array}$ \\
\hline SS6: & $\begin{array}{l}\text { ((I can)) listen. I understand what they say. I ((just can)) describe very clear my } \\
\text { point ... }\end{array}$ \\
\hline SS7: & I think they (international students) can know what I say. \\
\hline
\end{tabular}

Students were also asked what about the course was helpful for international communication. The students gave the following reasons (see Table 2). Their successful use of English to communicate with international students to complete administrative tasks was additional evidence that they benefited from the course (see Table 1).

Table 2: Students' course evaluation

\begin{tabular}{|l|l|}
\hline SS1: & $\begin{array}{l}\text {... The teacher taught me, teach us a good (course). Maybe I just think I am just } \\
\text { nervous but maybe I will talk with my classmates and then the teacher will give me } \\
\text { some suggestion and "you can do it". The teacher said, "you can do it" and then the } \\
\text { teacher will kindly taught us and "we can say it more" and ((sometimes)) ((I just)) } \\
\text { go down the other level (go to an advanced level) to study. }\end{array}$ \\
\hline SS2: & @ @ ((I think)) the vocabulary, the basic vocabulary yeah. \\
\hline SS3: & $\begin{array}{l}\text { Okay. ((I like)) very much speak with (the) teacher. It (the course) improved my } \\
\text { listening and press [?] my conversation nowadays I can speak English much than } \\
\text { before so I learn it much vocabulary, grammar I don't improve. @ @ But my } \\
\text { English listening is better than before. I ((I have)) courage to say much English. }\end{array}$ \\
\hline SS4: & $\begin{array}{l}\text { We have more time to talk with the teacher. And the teacher give us the responses } \\
\text { directly. ... If I have question, I can ask the teacher and the teacher give me the } \\
\text { responses very directly. In other classes, we have a lot of students so we don't have } \\
\text { time to ((ask)) the question or I don't dare to ask question. }\end{array}$ \\
\hline SS6: & $\begin{array}{l}\text { It (the course) gives me a lot of mobility or makes me more independent. More } \\
\text { open-minded. }\end{array}$ \\
\hline SS7: & $\begin{array}{l}\text { I am happy the management office give us the environment and chance to (attend) } \\
\text { the class and the class is funny and interesting because (with) the teacher, (we can) } \\
\text { say anything. ... I think it is ((different)) from the experience when I am junior high } \\
\text { school or and the college. It let me speak more. Yes. }\end{array}$ \\
\hline
\end{tabular}

The students expressed that the course was a catalyst for practical changes in their learning and use of English. Firstly, the students all highlighted the effectiveness of developing vocabulary skills for successful international communication (e.g., SS2). Secondly, students practised using English to converse (e.g., SS1). Students also appreciated the value of the language support from the upper management (e.g., SS7). 
After this course, the students: 1) became confident users of English willing to speak as much as they can (e.g., SS1, SS7), 2) spoke as freely as they could (e.g., SS7), and 3) became autonomous learners of English (e.g., SS6). While most of the existing literature has focused on students' conceptual changes and the implications of acquired knowledge from the courses for learning English (e.g., Chang 2014), the examples above illustrate practical changes in students' language learning.

Among the practical changes, the students became autonomous learners and users of English. While the students' learner autonomy developed, their English language fluency and communicative abilities also improved. This finding echoes Little's (1995, 179) argument that "the learner's acceptance of responsibility for his or her learning entails the gradual development of a capacity for independent and flexible use of the target language". In other words, the more autonomous and independent the students became, the more fluent and confident they became.

Apart from practical changes, the students also mentioned how they obtained direct support from upper management. For instance, the teacher answered students' queries about learning or this course directly (e.g., SS4), and they received professional support from the School of Management (e.g., SS7). Students' evaluation of this course pointed to the importance to consider contextual factors that determine whether courses can be successfully planned and implemented (McKay and Brown 2016).

\section{Teacher's Evaluation}

The evidence presented below shows a minimum impact of the linguistic normative approach on planning, teaching, and learning. Firstly, the vocabulary was selected by the dean and the students according to real-world communication experience and needs. The aim of the vocabulary learning was not to acquire a native-speaker-like vocabulary size. Instead, the learning of selected words enabled students to express and negotiate meaning. Secondly, the teacher indicated that he only intervened when he heard "something that was unintelligible" (Teacher interview two) or when students sought his advice in terms of international communication experience. Thirdly, the teacher's input allowed the students to revise. As mentioned, at the beginning of the course, 50\% of the content of the dialogues written by the teacher was revised by the students. Later, the students wrote the dialogues entirely by themselves. As can be seen, NS, monolingual, and Standard English ideology did not dominate this course. Supporting the findings of $\mathrm{Yu}$ (2018), the current study did not find the need for learning activities aimed at rejecting a linguistic normative approach.

When the teacher was asked about the major difference between this course and the previous language courses that he taught, he emphasised that he "can see a very clear result from having the ability to evaluate what students' needs are before teaching". In previously taught formal courses, he was expected to "start teaching on day one" and was given no time to "get to know students before getting to business" (Teacher interview two). Assessing students' needs before planning a course has also been 
advocated by previous researchers (McKay and Brown 2016). Pedagogical decisionmaking is often based on the teachers' assumptions about what students may need if there is no needs assessment. This highlights the importance of assessing students' needs before teaching begins. In this study, as the teacher suggested, it was important to assess students' needs prior to the start of the course in order to "create a specialised programme that targets the needs of students" (Teacher reflection report). However, if the teachers have experience in using English for international communication, teachers may still be in a good position to "determine what is relevant for their learners" (Leung and Lewkowicz 2018, 70).

As highlighted in our literature review, McKay and Brown (2016) argued that decisions related to teaching should not solely be based on teacher beliefs and should instead also consider contextual factors. As SS7 pointed out, she appreciated the School of Management arranging the training and creating opportunities for English use (see Table 2). The teacher also said:

Usually for courses, I am just given a title or syllabus and even in those situations where I have control over the content, there are some general guidelines that are laid out that I must follow. I was given freedom over the class that sort of empowered the students.... We had a lot of control over the content. It is a pity that in other courses I may not be granted this type of freedom, so it will be a bit impossible for what I have experienced in this class to transfer over to other classes. (Teacher reflection report)

Recognising the positive impact of this course on the students' language learning and use, the teacher firstly appreciated the support from the upper management, giving him "freedom" to teach and the students to learn. From the planning of this course to the end of its execution, the teacher showed that he had abilities to implement this course. These abilities included assessing the students' language needs, managing the learning materials, addressing the students' needs as well as the School of Management's requirements, developing students' learning autonomy and independence, drawing students' attention from learning to using English, and skillfully keeping a balance between his and the students' autonomy. The examples of the teacher's freedom to teach this course correspond to the definition of teacher autonomy put forth by Lamb (2008, 275 ) as "freedom to be able to teach in the ways that one wants to teach". The evidence also showed that the teacher successfully developed students' learner autonomy by helping them to identify, develop, and use essential materials to freely learn and use English for communication purposes. Helping students become autonomous learners and independent users of English in the classroom echoes Little's $(1995,180)$ argument that "language learners are more likely to operate as independent flexible users of their target language if their classroom experience has already pushed them in this direction".

\section{Limitations and Future Research Directions}

While the aim of a case study is not to make inferences about other contexts, it has provided insights into how an English for communication course can be implemented 
in the Taiwanese higher education context. While other Taiwanese contexts might take into consideration the findings of this study, it is best to delimit these results to informal non-credit bearing contexts. The amount of freedom that the teacher and students had in this course is not typical of formal English courses taught in Taiwan. Moreover, additional case studies within other higher education contexts in Taiwan and beyond are necessary to determine the transferability of implementing this teaching approach in other contexts. While much research has been conducted to gather academic staff and students' perceptions of the internationalisation of higher education and the role that English as a language of instruction plays, few studies have highlighted the voices of administrative staff (Reynolds and Yu 2016, 2018). Large-scale survey research conducted under a quantitative paradigm across multiple contexts is needed to bring the voices of this under-represented group of stakeholders to the forefront.

\section{Conclusion}

The findings from the current case have uncovered implications for the teaching of communicative language courses. The first implication is that a pre-determined syllabus or curriculum for local teachers to follow is not needed; students can also reap benefits in a locally planned language course executed from an international perspective. Secondly, local language courses aimed at preparing students for international communication can be better planned and effectively implemented when teacher and student autonomy is developed. Instead of using learning materials found in textbooks, students and teachers should have the option to collaboratively construct communicative dialogues that are relevant to the students' language needs. Thirdly, to understand what knowledge of the English language is necessary for local students to develop communicative competence, language needs assessment should be carried out before planning and teaching the courses. Lastly, developing EIL-oriented language courses should be seen as a process of altering the content of teaching and learning to ensure the relevance of the course to students' needs for communicative language use. To this end, a local English language course for international communication purposes should be collaboratively planned by the institutes, teachers, and students to make sure that the content of the course serves the communication needs of the specific student cohort.

The findings also highlight an insufficient understanding in the existing EIL, ELF, and WE studies. Firstly, these studies have paid more attention to EIL/ELF/WE-oriented course development for teacher training programmes and less attention to English language courses aimed at different student or professional cohorts. Secondly, the existing studies have investigated these courses as products of course development. These studies did not discuss or document the process of developing courses. Readers of this body of research are left questioning: 1) how these courses are developed, 2) who developed these courses, 3) against which educational backgrounds have the courses been developed, and 4) for what purposes have they been developed? Lastly, there is insufficient understanding of whether local in-service teachers need professional 
support to be able to plan and implement such courses or their related teaching activities. In order to understand locally planned EIL-oriented courses, the areas identified above point to new directions in which course development can be reconceptualised.

One locally planned language course to prepare students for international communication cannot necessarily be adopted in other contexts. Locally planned language courses are not developed in a vacuum. A case in point is this course, which obtained the support from the upper management as well as the development of learner and teacher autonomy. The results of this case study offer motivation for future studies to investigate the development of local English language courses for international communication with a focus on contextual factors.

\section{References}

Baker, W. 2015. "Culture and Complexity through English as a Lingua Franca: Rethinking Competences and Pedagogy in ELT". Journal of English as a Lingua Franca 4 (1): 9-30. https://doi.org/10.1515/jelf-2015-0005.

Coxhead, A. 2018. Vocabulary and English for Specific Purposes Research: Quantitative and Qualitative Perspectives. New York, NY: Routledge. https://doi.org/10.4324/9781315146478.

Chang, Y.-J. 2014. "Learning English Today: What Can World Englishes Teach College Students in Taiwan?" English Today 30 (1): 21-27. https://doi.org/10.1017/S0266078413000527.

Creswell, J. W. 2019. Educational Research: Planning, Conducting, and Evaluating Quantitative and Qualitative Research. Boston, MA: Pearson Education.

Drisko, J., and T. Maschi. 2013. Content Analysis. Oxford: Oxford University Press.

Dogancay-Aktuna, S., and J. Hardman. 2018. "Teaching of English as an International Language in Various Contexts: Nothing Is as Practical as Good Theory". RELC Journal 49 (1): 74-87. https://doi.org/10.1177/0033688217750642.

Fang, F., and W. Ren. 2018. “Developing Students' Awareness of Global Englishes”. ELT Journal 72 (4): 384-94. https://doi.org/10.1093/elt/ccy012.

Galloway, N., and H. Rose. 2018. "Incorporating Global Englishes into the ELT Classroom". ELT Journal 72 (1): 3-14. https://doi.org/10.1093/elt/ccx010.

Gao, X. 2018. "Language Teacher Autonomy and Social Censure”. In Autonomy in Language Learning and Teaching, edited by A. Chik, N. Aoki and R. Smith, 29-50. London: Palgrave. https://doi.org/10.1057/978-1-137-52998-5_3.

Given, L. M. 2008. The Sage Encyclopedia of Qualitative Research Methods. Thousand Oaks, CA: Sage Publications. https://doi.org/10.4135/9781412963909. 
Hall, C. J. 2014. "Moving beyond Accuracy: From Tests of English to Tests of 'Englishing"”. ELT Journal 68 (4): 376-85. https://doi.org/10.1093/elt/ccu016.

Hall, J. K., A. Cheng, and M. T. Carlson. 2006. "Reconceptualizing Multicompetence as a Theory of Language Knowledge”. Applied Linguistics 27 (2): 220-40. https://doi.org/10.1093/applin/aml013.

Jenkins, J. 2000. The Phonology of English as an International Language. Oxford: Oxford University Press.

Jenkins, J. 2015. Global Englishes: A Resource Book for Students. 3rd ed. New York, NY: Routledge.

Jenkins, J., and C. Leung. 2016. “Assessing English as a Lingua Franca”. In Language Testing and Assessment, edited by E. Shohamy, I. G. Or and S. May, 1-15. Cham: Springer International. https://doi.org/10.1007/978-3-319-02326-7_7-1.

Kang, S.-Y. 2017. “US-Based Teacher Education Program for 'Local' EIL Teachers”. In Preparing Teachers to Teach English as an International Language, edited by A. Matsuda, 51-65. Bristol: Multilingual Matters. https://doi.org/10.21832/9781783097036006.

Lamb, T. 2008. "Learner Autonomy and Teacher Autonomy: Synthesising an Agenda". In Learner and Teacher Autonomy: Concepts, Realities, and Responses, edited by T. Lamb and H. Reinders, 269-84. Amsterdam: John Benjamins. https://doi.org/10.1075/aals.1.21lam.

Leung, C., and J. Lewkowicz. 2018. "English Language Teaching: Pedagogic Reconnection with the Social Dimension". In The Routledge Handbook of English as a Lingua Franca, edited by J. Jenkins, W. Baker and M. Dewey, 61-73. London: Routledge. https://doi.org/10.4324/9781315717173-6.

Little, D. 1995. "Learning as Dialogue: The Dependence of Learner Autonomy on Teacher Autonomy”. System 23 (2): 175-81. https://doi.org/10.1016/0346-251X(95)00006-6.

Little, D. 2007. "Language Learner Autonomy: Some Fundamental Considerations Revisited". Innovation in Language Learning and Teaching 1 (1): 14-29. https://doi.org/10.2167/illt040.0.

Lu, Y.-L. 2018. "What Do Nurses Say about Their English Language Needs for Patient Care and Their ESP Coursework: The Case of Taiwanese Nurses". English for Specific Purposes 50: 116-29. https://doi.org/10.1016/j.esp.2017.12.004.

Matsuda, A. 2017. Preparing Teachers to Teach English as an International Language. Bristol: Multilingual Matters. https://doi.org/10.21832/9781783097036. 
McKay, S. L., and J. D. Brown. 2016. Teaching and Assessing EIL in Local Contexts around the World. New York, NY: Routledge.

Nation, I. S. P. 2007. “The Four Strands". Innovation in Language Learning and Teaching 1 (1): 2-13. https://doi.org/10.2167/illt039.0.

Nation, I. S. P. 2013. Learning Vocabulary in Another Language. Cambridge: Cambridge University Press. https://doi.org/10.1017/CBO9781139858656.

Nation, I. S. P., and A. Yamamoto. 2012. “Applying the Four Strands to Language Learning”. International Journal of Innovation in English Language Teaching 1 (2): 167-81.

Pennycook, A. 2012. Language and Mobility: Unexpected Places. Bristol: Multilingual Matters. https://doi.org/10.21832/9781847697653.

Pennycook, A., and E. Otsuji. 2015. Metrolingualism: Language in the City. London: Routledge. https://doi.org/10.4324/9781315724225.

Pinner, R. S. 2016. Reconceptualising Authenticity for English as a Global Language. Bristol: Multilingual Matters. https://doi.org/10.21832/9781783095681.

Reynolds, B. L., and M. H. Yu. 2016. "Using Web-Based Video Technologies to Increase Taiwanese University Staff's Willingness to Use ELF”. In Intercultural Communication: New Perspectives from ELF, edited by L. Lopriore and E. Grazzi, 131-44. Rome: Rome Tre Press.

Reynolds, B. L., and M. H. Yu. 2018. “Addressing the Language Needs of Administrative Staff in Taiwan's Internationalised Higher Education: Call for an English as a Lingua Franca Curriculum to Increase Communicative Competence and Willingness to Communicate". Language and Education 32 (2): 147-66. https://doi.org/10.1080/09500782.2017.1405017.

Richards, K. 2003. Qualitative Inquiry in TESOL. New York, NY: Palgrave Macmillan. https://doi.org/10.1057/9780230505056.

Rose, H., J. McKinley, and N. Galloway. 2021. “Global Englishes and Language Teaching: A Review of Pedagogical Research”. Language Teaching 54 (2): 157-89. https://doi.org/10.1017/S0261444820000518.

Seidlhofer, B. 2011. Understanding English as a Lingua Franca. Oxford: Oxford University Press.

Stake, R. E. 1995. The Art of Case Study Research. Thousand Oaks, CA: Sage Publications.

Sung, C. C. M. 2018. "Out-of-Class Communication and Awareness of English as a Lingua Franca”. ELT Journal 72 (1): 15-25. https://doi.org/10.1093/elt/ccx024. 
Tomlinson, B., and H. Masuhara. 2010. "Applications of the Research Results for Second Language Acquisition Theory and Research". In Research for Materials Development in Language Learning: Evidence for Best Practice, edited by B. Tomlison and H. Masuhara, 399-409. London: Continuum.

Wang, J., S.-I. Liang, and G. Ge. 2008. "Establishment of a Medical Academic Word List". English for Specific Purposes 27 (4): 442-58. https://doi.org/10.1016/j.esp.2008.05.003.

Widdowson, H. G. 1998. "Context, Community, and Authentic Language”. TESOL Quarterly 32 (4): 705-16. https://doi.org/10.2307/3588001.

Xu, Z. 2018. "Exploring English as an International Language-Curriculum, Materials and Pedagogical Strategies". RELC Journal 49 (1): 102-18.

https://doi.org/10.1177/0033688217753848.

Yu, M. H. 2015. "Developing Critical Classroom Practice for ELF Communication: A Taiwanese Case Study of ELT Materials Evaluation”. In International Perspectives on English as a Lingua Franca: Pedagogical Insights, edited by H. Bowles and A. Cogo, 3554. London: Palgrave Macmillan. https://doi.org/10.1057/9781137398093_3.

Yu, M. H. 2018. "Using Textbooks to Teach and Learn English for Lingua Franca Communication: An Insight into Classroom Autonomy”. The Asia-Pacific Education Researcher 27 (4): 257-66. 
Appendix 1

\section{A Reflection Guide for Students}

Section I: Job-related English language use and needs

1. How do you use English to communicate with international students?

a. Based on your communicative experience and preferences, could you give examples of effective ways to communicate with international students?

b. Did you learn your English skills through this course, your previous learning experience, or actual communicative experiences at work?

\section{Section II: Teacher's teaching}

2. How did you feel about being asked to write your own dialogues using your own ways to speak English?

a. Do you feel you are learning English, using English, or both?

b. What is your teacher's and peers' responses to your English use?

c. Which aspects of teaching effectively helped you become users of English?

d. How do you feel about or how do you evaluate your English language performance?

e. Did the teacher correct your English? Can you give examples?

f. How do you feel as a user of English?

\section{Section III: Evaluating your English language education from the past to the} current course

3. Can you briefly write about what Taiwanese English language education has offered you?

a. Did previous courses and the current course give you any opportunity to use English?

b. Prior to this course, did you find that the English you learned meets your language needs in workplaces?

c. Are you satisfied with the current course? Did you find it useful? Did it meet your language requirements for working in this university? 
Appendix 2

\section{A Reflection Guide for the Teacher}

1. Background information about this course

2. Course plan: how, when, why, for whom, by whom, which contexts, what materials, etc.

3. Teaching delivery

4. Learning and students 
Appendix 3

\section{Two Sets of Teacher E-mail Interview Questions}

Teacher Interviews constituted Interview I and II. Interview I focused on the teacher's professional background, the teacher's analysis of Taiwanese EFL contexts, and the teacher's teaching principles and practice. Interview II addressed the issues about the content and realisation of the planned language course.

\section{Interview I}

This interview is divided into three sections. The first section is about teaching experience and the teacher's educational background. The second section considers the teacher's understanding of the Taiwanese EFL context. The third section addresses principles and practice of teaching.

\section{Section 1: Information about the teacher's background}

The teacher's English language teaching experience

1. Could you tell me about your teaching experience (e.g., years of teaching, teaching contexts, courses taught)?

2. Could you give me examples of your teaching English for communication purposes before this course?

\section{The teacher's educational background}

1. Could you briefly describe your educational background?

2. When receiving teacher education, did you receive training about WE, EIL, and ELF? If yes, what courses did you take and how did you feel about them? Did you feel the knowledge you gained useful to your teaching in the Taiwanese context? If not from previous courses, how did you learn about ELF, WE, or EIL? Did you find any of this knowledge useful to your teaching in the Taiwanese context?

\section{Section 2: The teacher's perspective on Taiwanese EFL contexts}

\section{Language use}

1. How do you perceive Taiwanese people's English in general as a teacher as well as a foreigner in Taiwan?

2. How do you find international students' English and their communicative use with Taiwanese people?

3. Are there any further comments on Taiwanese people's English you would like to provide (e.g., anecdotes from other foreign friends)?

\section{Language teaching and learning}

1. In general, what about language teaching and learning do you think teachers and students in Taiwan have paid more or less attention to? 
2. What do you think of Taiwanese students' approach to English language education? Can you name the approaches used by your previous students which you think are useful and useless to preparing them for communicative language use?

\section{English as a lingua franca and internationalisation of higher education in the Taiwanese context}

1. What did you think of the university staff's English when you were an international student?

2. When you were an international student, how did you feel about local and international students' use of English to communicate with one other? Can you give me some examples?

\section{Section 3: The teacher's evaluation of his teaching}

1. How have you taught Taiwanese students or other EFL learners before this project?

2. Can you identify the major difference or changes in your teaching and ideas of learning English language before and after this research project?

3. While teaching during this research project, did you find any principles of teaching and learning particularly useful for students to develop their English?

4. What ideas of learning and teaching were not very effective or helpful in creating opportunities for language use?

\section{Interview II}

The following interview questions were formulated based on the teacher's reflection report and videoed classroom practices.

1. Why did you focus on vocabulary rather than grammar, pronunciation, or other linguistic input? Was this decision related to your expertise? Were there any theories or ideas of teaching English for intercultural communication that supported your decision?

2. In addition to students' scenarios for language use, what other resources did you refer to when you wrote the dialogues in the first two months? Did you add any ideas of yours when writing the dialogues? If yes, what were those ideas and why did you add them? If not, why not add some of your own ideas?

3. Can you tell me how your students practised English using the written dialogues and target vocabulary? Did they have to memorise the written conversations, or did they use other ways to practise English?

4. What made you decide that students should write their own dialogues? What theories of teaching or other ideas supported your decision?

5. Why did you think your students would be unwilling or not confident to use English in their own ways? Are there any examples of the ways you used or you think can make students confident in their English use?

6. Can you give examples of students' English which was intelligible or unintelligible to you? How did you make judgments about whether your students' 
English was internationally intelligible or unintelligible? Did students help you understand their English when it was unintelligible? How did the students do this?

7. Was the use of dialogue writing a strategy that you used to prepare students who have lower proficiency of English to become a user of English?

8. Can you tell me what kind of strategies you used to help students become English users? Do you find these strategies useful to your students to learn and use vocabulary? Why is that?

9. Do you find L1 resources can help your students use English? Could you give examples to support your viewpoint?

10. You stated in the reflection that students like vocabulary strategies. Do you mean they like the strategies because they find them useful for learning or using English? If not, what did you mean? 
Appendix 4

\section{Student Interview Questions}

1. How do you feel when you are communicating with foreign students? For example, do you feel it is difficult or easy to communicate with them?

2. Do you think you speak differently when talking to someone whose first language is English compared to someone whose first language is not English?

3. Do you think that after you have had this kind of experience with foreign students that there is anything that has changed about your attitude and/or perception of English learning?

4. Is there anything else that you would like to describe or just tell your feelings about when dealing with international students, learning English, or taking a training course like this one? Is there anything else you would like to add? You can share your feelings, or you can express your feelings about anything you would like to share. 
Appendix 5

Transcription Conventions

\begin{tabular}{|l||l|}
\hline SS1, SS2 ... & Pseudonyms \\
\hline$\ldots$ & Omission \\
\hline$(($ ) $)$ & The word(s)/phrase(s) are repeated \\
\hline$@ ~ @ ~$ & Laughter \\
\hline$[$ ] & Words added for clarification \\
\hline
\end{tabular}

